ELK ASIA PACIFIC JOURNAL OF SOCIAL SCIENCES

ISSN 2394-9392 (Online); DOI: 10.16962/EAPJSS/issn.2394-9392/2014; Volume 2 Issue 3 (2016)

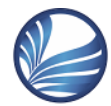

ELK

Asia Pacific Journals

www.elkjournals.com

\title{
CHALLENGES OF TEACHING ENGLISH AT THE RURAL PRIMARY SCHOOLS IN BANGLADESH: SOME RECOMMENDATIONS
}

Rashed Khan Milon
Lecturer, Department of English,
Port City International University, Chittagong,
Bangladesh

\begin{abstract}
Primary level education is the base of the students for their future. Every year many of our students fail in the public examination and even those who pass in the existing exam system by memorizing and without achieving four skills, cannot display enough competence in English. Primary level has been chosen as it is the basic level and the teachers are entirely responsible for the students' learning at this level. The main purpose of this study was to find out the challenges in teaching -learning English at the Primary level of rural area in Bangladesh. In this study two sets of questionnaire were used to collect data from the students and the teachers to evaluate the situation of English language teaching-learning in the primary schools of the rural areas in Bangladesh. Interviews were also taken from the teachers and English teaching sessions were observed using an observation checklist to find out the real present scenario of teaching English language at the primary level. The study indicates that most of the rural schools' students are weak in English due to lack of skilled and trained teachers, proper teacher training, using proper teaching methods and materials, limited contact hours, class size, inadequate knowledge on pedagogy and so on. Some recommendations based on research findings have also been included in this paper to face those challenges.
\end{abstract}

Key words: English language, challenges, curriculum, CLT, rural primary level schools.

\section{Introduction}

In the National Education Policy- 2010, the primary curriculum has been revised and emphasis has been given on learning English as an international language for communicating locally and globally. The
English text books of this level have been developed for the learners to attain four language skills through meaningful and enjoyable activities. Emphasis has been given on listening and speaking skills as the 


\section{ELK ASIA PACIFIC JOURNAL OF SOCIAL SCIENCES}

ISSN 2394-9392 (Online); DOI: 10.16962/EAPJSS/issn.2394-9392/2014; Volume 2 Issue 3 (2016)

foundation on which to develop reading and writing skills.

The main purpose of using language is to communicate one's needs, necessities, feelings, thoughts and ideas to others (Banu,2009). Empirical studies indicate that many of the primary graduates are failing to learn language skills that they can use effectively(Snow, Burns \& Griffin, 1998; Ahmed \& Nath, 2005).To learn language, comprehension strategies need to be more explicitly discussed and individual interpretation of texts need to be valued inside the classroom (Nath and Hossain, 2005). Children need to learn different reading strategies. For example, scanning, skimming and locating information throughout the text to solve different reading problems. All learning experiences do not necessarily lead to learning, unless subsequent opportunities for reflection, application, correlation and consolidation are created (Shukla, 2008). In case of English language teaching (ELT), several methodologists (Littlewood,1981; Richards and Rodgers, 1986; Tudor, 1993; Harmer, 2001) have suggested many potential roles for a language teacher. Richards and Rodgers (1986) consider teachers' roles as part of the 'design' component of a method, pointing out that these are related to the types of function teachers are expected to fulfill, the degree of control the teacher has over how learning takes place, the degree to which is the teacher is responsible for determining the content of what is taught, and the interactional patterns that develop between teachers and learners. Littlewood (1981) conceptualizes the role of the language teacher broadly as the "facilitator of learning" in the context of Communicative Language Teaching (CLT) instead of the rather narrow concept of the "teacher as instructor". According to Littlewood (1981), a teacher's role as a facilitator entails the sub-roles of an "overseer" of student's learning, a "classroom manager", a "consultant or adviser" and sometimes, a "cocommunicator" with the learners. Harmer (2001) looks at them "facilitator" in a much broader way than Littlewood does, and points out that the ultimate aim of all roles is to facilitate the students' progress in some way or the other. He talks about using certain "precise" terms for the roles that teachers play in the classroom: controller, organizer, assessor, prompter, participant, resource, tutor and observer. Tudor(1993) looks at the role of the teacher in the context of the notion of the learner -centered 


\section{ELK ASIA PACIFIC JOURNAL OF SOCIAL SCIENCES}

ISSN 2394-9392 (Online); DOI: 10.16962/EAPJSS/issn.2394-9392/2014; Volume 2 Issue 3 (2016)

classroom, a kind of classroom in which the focus is on the active involvement of the learners in the learning process. Interactive communication in collaborative learning experiences help learners to develop their thinking through language and develop their language through thinking. Significant changes have been experienced in the communication dynamics of the world. English as a lingua franca has a paramount importance in equipping the students to take up the challenges of the competitive survival and growing globalization in developing countries. This is high time we started to see the future development of English as a world language and took proper initiatives to get learners to the global standard level. The global distributions of English are often described in terms of three contexts such as English as a Native Language (ENL), English as a Second Language(ESL) and English as a Foreign Language(EFL).The main objectives of teaching English in primary level education in Bangladesh are to enable students to understand simple commands, requests and instructions in English and carry them out. The students can speak and converse in simple English and also can read to comprehend the textbooks set for their age group and level. They also write words, simple sentences, passages, paragraphs, informal letters and numbers according to their age group and level. Although NCTB prepared English curriculum for the students of the primary level schools to consider proper approaches and methods, unfortunately the curriculum is not applied accurately especially in the rural areas. However, most of the students of the rural primary schools are unable to attain the primary English language competencies due to prevailing challenges in our education system.

\subsection{Present situation of English language in Bangladesh:}

Necessity of teaching English was addressed first time in the South Asian subcontinent in Lord Macaulay's Minute of 1835 (Krishnaswamy and Sriraman, 1995). Macaulay in his Minutes expressed the importance of education that would be given to the natives through the medium of English. He mentioned two objectives of such education. The first was to create a class of natives who despite their blood and color through this education; would be English in culture and be able to "interpret" between the rulers and the subjects. The second was to create a "demand" for the European institutions. Clearly both the objectives were designed to serve the 


\section{ELK ASIA PACIFIC JOURNAL OF SOCIAL SCIENCES}

ISSN 2394-9392 (Online); DOI: 10.16962/EAPJSS/issn.2394-9392/2014; Volume 2 Issue 3 (2016)

interest of the Masters, not of the Subjects. When it published, he said, "It would be the proudest day in English History" (Sadek,2002). In Bangladesh, during the Pakistan period, as a legacy for British rule, English was a second language. The educated or even fairly educated people had to use English in offices, profession, education and other purposes. However, after the war of liberation in 1971, in independent Bangladesh, the official status of the English language changed to a foreign language. Moreover, recently the EFL situation in post liberation Bangladesh, English has regained an important unofficial status. There are about 90,000primary schools in the country where approximately 17 million students are studying. Teacher population is 264177 and teacher - student ratio is 1:56. It is the highest ratio between teacher and student among all levels of education (Raju,2003).English is being used in many government, semi- government and private organizations along with Bangla. In every level of education, there is a curriculum. Curriculum means a set of teaching materials that are taught in a school or a program. English curriculum at primary level of Bangladesh indicates the aim, teaching methods and techniques, teaching aids and evaluation system. To make
English study effective from the primary to the tertiary level a lot of things like trained teachers, communicative teaching materials, financial, infra-structural and management amenities are required. But, these things are not available in the rural primary schools in our country. Teaching - learning in the rural areas is very pathetic. Here learning means memorizing only grammatical rules and textbook contents even without understanding. But unfortunately, there is discrimination between the urban and the rural students' learning in case of English. The urban students have the easy access to watch cable television, go cyber café and read English newspapers. As a result they have the easy opportunity to use English outside their classroom. Besides, in some urban schools, computer education has been made mandatory from the very early of their schooling. This helps them to learn and to use English words and vocabulary. Their proficiency level is much higher than that of the rural students. It is notified in the public examinations and in the interviews.

\section{Research objectives:}

The main aim of this study was to find out the challenges of applying English curriculum at primary level in rural schools of Bangladesh. To investigate the 


\section{ELK ASIA PACIFIC JOURNAL OF SOCIAL SCIENCES}

ISSN 2394-9392 (Online); DOI: 10.16962/EAPJSS/issn.2394-9392/2014; Volume 2 Issue 3 (2016)

challenges, the specific objectives of this study are-

1. To find out the present situation of English teaching -learning methods in primary rural schools of Bangladesh.

2. To identify the challenges to apply the English curriculum in primary rural schools of Bangladesh.

3. To provide some recommendations to emancipate from the challenges of implementing the English curriculum at the rural primary schools of Bangladesh.

\section{Methodology}

The study was concerned to investigate the present situation of English teachinglearning processes in rural areas and to identify the nature of the problems to implement the English curriculum in Bangladesh. It was designed in mixed approach. Two sets of questionnaire (teachers and students), observation checklist were used to follow the quantitative approach while interview was conducted as the qualitative approach.

This research was conducted in the rural area of Shahrasti Upazila under Chandpur district, Bangladesh. There are 63 primary schools in the Upazila. To select the sample of schools, purposive sampling procedure was used. 20 schools were selected for collecting data. For selecting students, only class III, IV and V were considered. Class I and II were not considered as English is not taught formally at these levels. 20 teachers, one from each school and 200 students, 10 from each school were selected for data collection. 20 selected English teachers from each school, whose classes were observed, were considered as respondents for data collection through questionnaire; and other 10 English teachers, whose classes were not observed, were selected for interviews to find out in depth information. The questionnaire for the students was included mostly close ended and some open ended questions. Another questionnaire was used for the teachers whose classes were observed to find out the present situation of English teaching at primary level in rural areas. 10 English teachers, whose classes were not observed, were selected by purposive sampling for interviews. Interview was conducted to investigate the teachers' views about the challenges of teaching-learning English Curriculum at rural primary schools. Observation checklist was used to find out classroom teaching- 


\section{ELK ASIA PACIFIC JOURNAL OF SOCIAL SCIENCES}

ISSN 2394-9392 (Online); DOI: 10.16962/EAPJSS/issn.2394-9392/2014; Volume 2 Issue 3 (2016)

learning conditions and procedures towards English language learning.

\section{Results and Discussion}

\section{(Refer table 1 here)}

From all respondents, 55\% consent that they read English regularly whether $45 \%$ consent that they do not read English regularly. Among the respondents who do not read English regularly, $86 \%$ believe that English is very hard, 5\% do not get interest in English and 9\% students think that teachers do not make them understand precisely and as a result they do not like to study English. 5\% learn lessons understanding by themselves, $5 \%$ learn in teacher's class, $40 \%$ learn by reading guide books, $50 \%$ learn with the help of private tutors. Among the all respondents, $8 \%$ consent that English teachers make speaking exercise in the classroom while $40 \%$ consent that English teachers sometimes make speaking exercise in the classroom and 52\% admit that English teachers rarely make speaking exercise in the classroom. Most of the students claim that teachers do not make regular writing exercise in the classroom. Only $10 \%$ consent that English teachers make writing exercise regularly in the classroom while $60 \%$ consent that English teachers sometimes make writing exercise in the classroom whether 30\% think that English teachers rarely make writing exercise in the class. From all the respondents, $18 \%$ consent that English teachers always make reading exercise in the class whether $70 \%$ consent that English teachers sometimes make reading exercise and 12\% think that English teachers rarely make reading exercise in the class. Unfortunately, all the learners claim that no primary teacher make listening practice in classroom.

\section{(Refer table 2 here)}

Among all the respondents, 30\% teacher consent that they sometimes follow the teacher's guide; whereas $70 \%$ teacher do not follow teaching process instructed by the teacher guide. $18 \%$ teacher consent that they know the aims, objectives of primary level whether $82 \%$ teacher do not know the aims, objectives of primary level. 55\% participated in training for professional development, whereas $45 \%$ did not take any professional development training. 22\% teacher have taken training to teach English; whether it is horrified that $78 \%$ teacher have not taken any training to teach English. 32\% consent that they teach after making lesson plan; whereas $68 \%$ consent that they do not make lesson plan to teach. $60 \%$ teacher 


\section{ELK ASIA PACIFIC JOURNAL OF SOCIAL SCIENCES}

ISSN 2394-9392 (Online); DOI: 10.16962/EAPJSS/issn.2394-9392/2014; Volume 2 Issue 3 (2016)

consent that they give lesson in the class in Bangla language, $6 \%$ consent that they take class by using English and 34\% consent that they use both Bangla and English. 6\% teacher always use teaching aid to teach English; whether $42 \%$ often use teaching aids and $52 \%$ never use teaching aid to teach English.

\section{(Refer table 3 here)}

From the observation of classroom, it was found that $2 \%$ teachers are excellent in terms of classroom management, $10 \%$ teachers are good in terms of classroom management, $38 \%$ are in average performer, and $40 \%$ are in below average conditions; whereas $10 \%$ are totally unable in terms of classroom management. $32 \%$ teachers are in average condition in terms of students' motivation towards learning which is measured on the basis of using various ways of giving motivation, $60 \%$ are in below average means they try little bit to motivate their students whereas $8 \%$ teachers do not have any intension to teach students perfectly and they do not try to motivate students towards learning. 5\% students are good in terms of learner's participation in the classroom activities, $10 \%$ are in average while $85 \%$ are in below average which focus that students are inactive to the classroom as a result they can't learn properly. $8 \%$ teachers have good depth knowledge of subject matter, $20 \%$ have average in depth knowledge and $66 \%$ are in below average which focus that most of the teachers are not good at English language as a result they cannot teach properly. $28 \%$ school have average classroom learning environment, $72 \%$ have below average classroom learning environment. 5\% teachers are excellent in time management while $21 \%$ are good in time management, $34 \%$ are in average in time management, $26 \%$ are below average in time management and $16 \%$ teachers do not maintain any time schedule which affect students' learning. $6 \%$ teachers followed excellent evaluation technique and $23 \%$ are good in using technique of evaluation, $14 \%$ are in average, $27 \%$ are in below average and $31 \%$ are totally unable to use technique of evaluation as a result they cannot evaluate students' learning. $2 \%$ teachers have excellent feedback ability while $18 \%$ have good feedback ability and $27 \%$ average skill to give appropriate feedback, $22 \%$ are in below average and $32 \%$ teachers have no skills or do not give feedback to the students' learning. 


\section{ELK ASIA PACIFIC JOURNAL OF SOCIAL SCIENCES}

ISSN 2394-9392 (Online); DOI: 10.16962/EAPJSS/issn.2394-9392/2014; Volume 2 Issue 3 (2016)

\subsection{Interview of teachers:}

Ten English teachers, whose classes were not observed, were selected for interviews. Interview was taken to find out the depth information about the rural primary school education. Teachers' responses have been explained in qualitative approach.

English subject related training: Most of the teachers consented that they did not take any subject related training from the PTI except one year Certificate in Education(C-in-ED) training that is compulsory for all primary school teachers.

Management of classroom: Most of the teachers told that at first they call the students" roll and then asked them to open their books. Later they asked about their homework and next they usually started their teaching using the textbooks. They tried to make students understand their lessons. If any student raises any questions, they tried to solve the problem and later they give home work and leave the class. One of the teachers from the ten said that at first he tried to motivate the students and then started his lesson by telling some related stories. He tried to explain the English lesson carefully and gave feedback.
Teaching aids: Most of the teachers consent that they do not get any support for using extra teaching support from the school, government and non- government donor agencies except blackboard, chalk and duster. Besides, they are to take eight classes on average and so, they do not feel any interest to use extra teaching aids.

Contact hours: All of the teachers in this study consent that they are given 35 to 40 minutes to complete their classes. As a result they try to complete the syllabus in any way by one academic year.

Implementation of teaching -learning techniques mentioned in the curriculum: All of the teachers in this study claim that they cannot follow the mentioned teaching learning techniques in the curriculum due to large number of students and the worse learning environment.

Steps taken for the learners to be attentive in the class: Most of the teachers admit that they do not take any step for the students to become active in the class. If anyone makes noises, they try to stop. But two teachers claim that they make students active by using group work, pair work and throwing questions. In such processes, they try to 


\section{ELK ASIA PACIFIC JOURNAL OF SOCIAL SCIENCES}

ISSN 2394-9392 (Online); DOI: 10.16962/EAPJSS/issn.2394-9392/2014; Volume 2 Issue 3 (2016)

make the learners active for effective English language learning.

Steps taken for the weak and special featured students in teaching: Most of the teachers admit that they give priority to the weak and special featured students. They try to make them understand the subject matter again. Two teachers claim that they sometimes call their parents and tell them about their duties to their children and sometimes they go their home to motivate them.

Steps taken for achieving the learning objective: All of the teachers in this study claim that they do not have apparent idea about the learning objectives and they do not have any skills to measure the learning objectives achieved or not.

Problems for implementing English curriculum in school: All of the teachers claim that there are many problems to implement English curriculum such as high student - teacher ratio, small class size, insufficient teaching aids, lack of subject based training, unavailability of teacher guide, scarcity of language lab, proper physical facilities such as school building, classroom size, electricity supply, library and books availability hygienic toilet etc. are also liable for learning environment.

Suggestions to overcome English curriculum implementation problems: All the interviews consent that to face these problems government should take proper steps such as recruit more teachers in primary schools to reduce teacher - student ratio, to increase contact hours, to provide more teaching aids, subject based training and to assure the supply of teacher guide in time. They also suggest that various NGOs can also help to solve those problems.

\section{Findings and discussions}

To be skilled in a language especially the language which is not mother tongue is needed regular practice (Sadek, 2002). In this study it is found that English seems to be a terrifying subject to the rural students though they try their utmost to read English regularly. In Bangladesh, most of the primary schools are located in rural areas. Being majority in number, these schools are deprived of modern amenities for learning. As a result, it directly hampers students' English learning and it is the cause of students' menace in English. English seems to be obscure language to the rural students because teachers do not use any jovial 


\section{ELK ASIA PACIFIC JOURNAL OF SOCIAL SCIENCES}

ISSN 2394-9392 (Online); DOI: 10.16962/EAPJSS/issn.2394-9392/2014; Volume 2 Issue 3 (2016)

learning strategy. For this reason, most of the rural students can not make good result in English.

It is found that all school authorities are callous in English language learning. Most of the teachers complain that they do not get any help especially in teaching-learning materials from the school authority which is responsible for weak teaching. The school authorities are always busy to get money for themselves without considering the welfare of the school. Actually it is one of the main challenges for which teachers cannot use effective methodology in class room and that is liable to poor proficiency in English language in rural areas.

It is found that most of the teachers do not have any training in English which is essential for the development of their professional skill. Trained teachers are reluctant to use their training as they are rarely supervised. Although primary teachers are expected to teach English as a compulsory subject from class one, there is no ELT provision in PTIs (Primary Training Institute). As a result, they do not know how to teach English effectively. It is found that most of the teachers are ignorant of modern method except lecture method. It is a pressing matter and so, English turns out to be dull and hard subject to the learners.

Teachers' guide is an important instrumental material which helps to follow proper teaching instructions. But in this study, most of the teachers complain that they do not have teachers' guide though some teachers heard about the guide. As a result, they are unable to conduct English class fruitfully.

Curriculum is the heart of education system which indicates the education aim, objectives and learning outcomes. It helps teachers to conduct their teaching in classroom. But this research found that most of the teachers are not aware of the curriculum. So, it is one of the main obstacles for implementing curriculum. For this lacking of curriculum knowledge, the learners may be affected in English language proficiency.

Lesson plan is the preparatory teachinglearning materials which facilitate teachers to conduct classes effectively. But it is found in this research that the teachers are to take eight classes on average per day as a result they cannot make any lesson plan.

Teaching aids and instrumental materials are essential to motivate student towards 


\section{ELK ASIA PACIFIC JOURNAL OF SOCIAL SCIENCES}

ISSN 2394-9392 (Online); DOI: 10.16962/EAPJSS/issn.2394-9392/2014; Volume 2 Issue 3 (2016)

learning and to capture the English content knowledge easily. But it was found that the teachers do not use any extra teaching aids except chalk and duster to attract the learners.

Continuous assessment system and giving feedback is essential to judge students' achievement, weakness and emancipation of weakness in any subject. But it is found in this research that most of the teachers neglect continuous assessment system and show lethargy to give feedback which is also liable to lag behind in learning English.

The main aim of English language teaching at primary level is that the students will understand simple instructions in English and carry them out. But there is no practice of listening activities in the class room. Listening is an important skill of language learning. Without listening practice of English language, perfect pronunciation and speaking style cannot be followed (Sadek,2002).But it is found that no schools have any listening lab or listening instruments which is an unexpected scenario for learning English. It is found in this research that most of the teachers rarely practice speaking in the classroom while they sometimes make reading and writing practice. Besides, all the primary school teachers conduct their English classes by using Bangla language. Although, they try to make writing and reading practice, the ways of writing and reading practice is still questionable because they do not know the proper way of practicing of these skills. It is an alarming concern that many rural primary school teachers cannot write a piece of text of their own. They hardly listen to any English TV program. They rarely read any English newspaper or any book written in English. While teaching, these teachers think only of their students 'easy way for cutting good figures in the examinations.

Lack of adequate English teachers in the schools is also a concerning matter for which teachers of other subjects have to give the English classes but they do not have in depth knowledge in English. In both categories of Government and NonGovernment primary schools, there are no sufficient English language teachers. Thus, English subject based teacher recruitment in primary schools should be given as a prior issue that can enhance the English language learning at the primary level schools in Bangladesh. 


\section{ELK ASIA PACIFIC JOURNAL OF SOCIAL SCIENCES}

ISSN 2394-9392 (Online); DOI: 10.16962/EAPJSS/issn.2394-9392/2014; Volume 2 Issue 3 (2016)

\section{Recommendations}

1. More English teachers should be recruited.

2. Duration of the class should be increased.

3. Large classes should be divided into several sections with less than 30 students.

4. More training on Communicative Language Teaching approach should be arranged for the teachers.

5. More teaching aids especially audiovisual materials should be provided in the classroom

6. Teachers should be trained under PLTP programme on an urgent basis.

7. Speaking and listening activities should be emphasized more.

8. Test of speaking and listening skill should be included in the exams.

9. The teachers must assess the mood of the pupils. The time of the day influences the mood of the pupils. For example, early in the morning their concentration and interest is high compared to the time before the interval. Most of the students don't take their breakfast before going to school. Early morning period is recommendable for a full force lesson but before interval and before class dismiss it is advisable to have a light lesson not concentrating too much of drilling.

10. Response from the students during the lesson is important and it should be administered professionally.

11. To encourage the students to speak English, the teachers must use translation method. To apply translation method, the teachers have to give the learners a language chart in which the rule of preparing sentence would be given. For example, a chart for basic use as going to the toilet, classroom, meeting a teacher, Greetings such as good morning/ afternoon/night, may I borrow and so on. These structures must have to drill and hung in the classroom for the learners to remember and use when it is needed.

12. Remedial classes have to make compulsory for the weaker students and they aren't charged for remaining absent in the class.

13. The teachers can encourage the students to recite poem and they can arrange poetry recital competitions at the end of every month. Besides, other English language competition 


\section{ELK ASIA PACIFIC JOURNAL OF SOCIAL SCIENCES}

ISSN 2394-9392 (Online); DOI: 10.16962/EAPJSS/issn.2394-9392/2014; Volume 2 Issue 3 (2016)

will have to be carried out throughout the year.

14. The teachers have to stimulate the learners by passing an interesting problem.

\section{Conclusion}

The Bangladesh Government has taken various steps such as Compulsory Primary Education, Zila Prathamik Shiksha etc. for the improvement of the rural people of Bangladesh. To cope up with the needs of the learners, National Education Policy-2010 has been passed. The progress should be noticed by a project and research should be done. This study aimed at identifying some challenges in teaching-learning English at primary level in rural areas of Bangladesh and the study revealed that teachers' inadequate knowledge on pedagogy, higher student-teacher ratio, class size, limited contact hours, lack of proper teachers' training, lack of quality teachers, unavailability of language skills learning tools are the most problematic factors. Measures such as recruiting high qualified and subject specialist teacher, providing adequate training for their professional development, increasing salary level so that they can respect their own jobs, providing sufficient teaching aids for learning language skills, wide-ranging awareness programmes, changes in the learning methods and techniques, making classroom activities more experimental and enjoyable for the children and of course upgrading the school infrastructure are required for the solution of these problems. Here we would like to encourage other researchers to do a comparative study about urban and rural students' competency in English language and find out the solutions to overcome the thwarts of English language learning. As English is a global language, we cannot expect development by keeping the problems alive. It can be affirmed that the addressed issues will ensure a congenial teaching environment at the rural primary level schools in Bangladesh. 


\section{ELK ASIA PACIFIC JOURNAL OF SOCIAL SCIENCES}

ISSN 2394-9392 (Online); DOI: 10.16962/EAPJSS/issn.2394-9392/2014; Volume 2 Issue 3 (2016)

\section{References}

1. Ahmed, M. \&Nath, S. R. (2005).Quality with Equity: The Primary Education Agenda. Dhaka:Campaign for Popular Education.

2. Banu, L. F. A. (2009). Problems and Misconceptions Facing the Primary Language Education in Bangladesh: An Analysis of Curricular and Pedagogic Practices. BRAC University Journal. Institute of Educational Development, BRAC University (IED - BU).1: 1-10.

3. Bhattacharya, R. (2015). Difficulties in Teaching English at the Primary level in Bangladesh: Some Recommendations. Bangladesh Research Publications Journal. May 2015. Vol.11, Issue:2, pp:149-153.

4. Harmer, J. (2001).The practice of English language teaching. $3^{\text {rd }}$ ed. Longman. London.

5. Hossain, Nessa. \&Kafi.(2015). Challenges of Teaching English Language at the Primary Level Schools in Bangladesh. Banglavision Research Journal. April 2015. Vol.15, No.1
6. Krishnaswamy, N. \&Sriraman, T. (1995). English Teaching in India. Madras: T. R. Publications.

7. Littlewood, W. (1981).Communicative Language Teaching: An Introduction. Cambridge University Press. Cambridge. 92 pp.

8. National Curriculum and Textbook Board (2006).Compulsory curriculum (primary education).Retrieved January 23, 2012, from www.bangladeshdir.com/.../national_ curriculum_and_textbook_board_nct b_html

9. Raju, A. M. (2003). Present Condition of Primary Education in Bangladesh. Unpublished Master's Thesis, IER, University of Dhaka. Richards, J. C. \& Rodgers, T. (1986). Approaches and methods in language teaching: A description and analysis. Cambridge University Press. Cambridge. 24 pp.

10. Sadek, M. A. (2002). The Problems of English Language Teaching at Primary Level in Rural School of Bangladesh.Unpublished Master's Thesis, IER, University of Dhaka. 


\section{ELK ASIA PACIFIC JOURNAL OF SOCIAL SCIENCES}

ISSN 2394-9392 (Online); DOI: 10.16962/EAPJSS/issn.2394-9392/2014; Volume 2 Issue 3 (2016)

11. Salahuddin, Khan. \& Rahman (2013).Challenges of Implementing English Curriculum at Rural Primary Schools of Bangladesh.The International Journal of Social Sciences. 30 ${ }^{\text {th }}$ January 2013. Vol.7 No.

12. Snow, C.E., Burns, M.S., \& Griffin, P. (Eds).(1998). Preventing reading difficulties in young
children.Washington DC: National Academy Press.

13. Tudor, I. (1993). Teacher roles in the learner-centeed classroom. ELT Journal.47(1):22-3

10.1093/elt/47.1.22 


\section{ELK ASIA PACIFIC JOURNAL OF SOCIAL SCIENCES}

ISSN 2394-9392 (Online); DOI: 10.16962/EAPJSS/issn.2394-9392/2014; Volume 2 Issue 3 (2016)

\section{List of Tables:}

Table-1: Basic facts from students' interviews

\begin{tabular}{|l|l|}
\hline Statements & Percentage \\
\hline Studying English regularly in the classroom & 55 \\
\hline Ways of capturing lesson & 5 \\
\hline Speaking exercise in the classroom & 8 \\
\hline Writing exercise in the classroom & 10 \\
\hline Reading exercise in the classroom & 18 \\
\hline Listening exercise in the classroom & 00 \\
\hline
\end{tabular}

Table-2: Results from teachers' interviews

\begin{tabular}{|l|l|}
\hline Statements & Percentage \\
\hline Follow the instructions of teachers' guide & 30 \\
\hline Knowledge about the aims, objectives of English & 18 \\
\hline Training participation for professional skill development & 55 \\
\hline Training to teach English & 22 \\
\hline Lesson plan preparation & 32 \\
\hline Using of language in English class & 6 \\
\hline Use of teaching aid and instrumental materials to teach English & 6 \\
\hline
\end{tabular}




\section{ELK ASIA PACIFIC JOURNAL OF SOCIAL SCIENCES}

ISSN 2394-9392 (Online); DOI: 10.16962/EAPJSS/issn.2394-9392/2014; Volume 2 Issue 3 (2016)

Table-3: Classroom observation checklist

\begin{tabular}{|l|l|l|l|l|l|}
\hline \multirow{2}{*}{ Statement } & \multicolumn{4}{l}{ Scale } & \multicolumn{4}{l|}{} \\
\cline { 2 - 7 } & Excellent & Good & Average & Bellow & Unable \\
\hline Classroom management & 2 & 10 & 38 & 40 & 10 \\
\hline Students' motivation towards & - & - & 32 & 60 & 8 \\
\hline Learners' participation in & - & 5 & 10 & 85 & - \\
\hline Teachers' in depth knowledge & - & 8 & 20 & 66 & 7 \\
\hline Classroom learning & - & - & 28 & 72 & \\
\hline Time management & 5 & 21 & 34 & 26 & 16 \\
\hline Technique of evaluation & 6 & 23 & 14 & 27 & 31 \\
\hline Ways of giving feedback & 2 & 18 & 27 & 22 & 32 \\
\hline
\end{tabular}

